Keywords: CD44 variant 2; CD133; xenograft; prognostic marker; colorectal cancer; cancer stem cell; leucine-rich-repeat containing $\mathrm{G}$ protein-coupled receptor 5

\title{
Prognostic significance of CD44 variant 2 upregulation in colorectal cancer
}

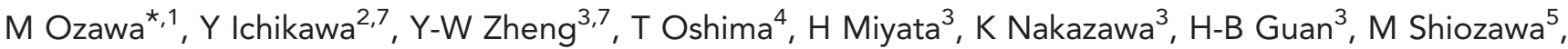

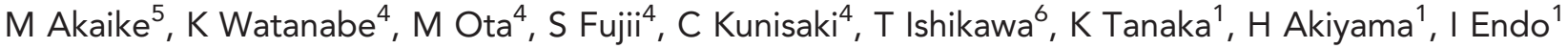 \\ and $\mathrm{H}$ Taniguchi ${ }^{\star}, 3$
}

${ }^{1}$ Department of Gastroenterological Surgery, Yokohama City University, 3-9 Fukuura Kanazawa-ku Yokohama-shi, Kanagawa-ken 236-0004, Japan; '2Department of Clinical Oncology, Yokohama City University, 3-9 Fukuura Kanazawa-ku Yokohama-shi, Kanagawa-ken 236-0004, Japan; ${ }^{3}$ Department of Regenerative Medicine, Yokohama City University, 3-9 Fukuura Kanazawa-ku Yokohama-shi, Kanagawa-ken 236-0004, Japan; ${ }^{4}$ Gastroenterological Center, Yokohama City University Medical Center, $4-57$ Urafune Minami-ku Yokohama-shi, Kanagawa-ken 232-0024, Japan; ${ }^{5}$ Department of Surgery, Kanagawa Cancer Center, 2-3-2 Nakao Asahi-ku Yokohama-shi, Kanagawa-ken 241-8515, Japan and 'Breast and Thyroid Surgery, Yokohama City University Medical Center, 4-57 Urafune Minami-ku Yokohama-shi, Kanagawa-ken 232-0024, Japan

Background: CD133 and CD44 are putative cancer stem cell (CSC) markers in colorectal cancer (CRC). However, their clinical significance is currently unclear. Here, we evaluated primary CRC cell isolates to determine the significance of several CSC markers, including CD133 and CD44, as predictors of tumourigenesis and prognosis.

Methods: CD133- and CD44-positive cells from fresh clinical samples of 77 CRCs were selected by flow cytometric sorting and evaluated for tumourigenicity following subcutaneous transplantation into NOD/SCID mice. Cancer stem cell marker expression was examined in both xenografts and a complementary DNA library compiled from 167 CRC patient samples.

Results: $\mathrm{CD}_{4}{ }^{+}, \mathrm{CD}_{133^{+}}$and $\mathrm{CD} 133^{+} \mathrm{CD} 44^{+}$sub-populations were significantly more tumourigenic than the total cell population. The clinical samples expressed several transcript variants of CD44. Variant 2 was specifically overexpressed in both primary tumours and xenografts in comparison with the normal mucosa. A prognostic assay using qRT-PCR showed that the CD44v2 ${ }^{\text {high }}$ group ( $n=84,5$-year survival rate (5-OS): 0.74$)$ had a significantly worse prognosis $(P=0.041)$ than the CD44v2 ${ }^{\text {low }}$ group $(n=83,5-O S: 0.88)$.

Conclusions: CD44 is an important CSC marker in CRC patients. Furthermore, CRC patients with high expression of CD44v2 have a poorer prognosis than patients with other CD44 variants.

Within many solid cancers, there is considerable heterogeneity in phenotypic, genetic and epigenetic traits. The plasticity of a minor sub-population of cancer stem cells (CSCs) is thought to contribute to intercellular heterogeneity and the emergence of therapeutic resistance. Therefore, CSCs are potentially critical targets for novel cancer treatments (Reya et al, 2001). Although the presence of CSCs may, in some cases, be a strong predictor of tumourigenesis and prognosis (Jessup et al, 1989), there is no 'standard' genetic or epigenetic marker for CSCs across tumour types.
Several markers are associated with CSC in colorectal cancer (CRC), including CD24, CD29, CD44, CD133, CD166, the epithelial cell adhesion molecule, Musashi-1, aldehyde dehydrogenase-1 (ALDH1) and the leucine-rich-repeat containing G protein-coupled receptor 5 (LGR5; Todaro et al, 2010). CD133 ${ }^{+}$ and $\mathrm{CD} 44^{+}$cell populations represent a particular subset of aggressive CRC cells (Dalerba et al, 2007; O’Brien et al, 2007; RicciVitiani et al, 2007; Du et al, 2008). However, there has been insufficient evaluation of these markers using clinical samples in

\footnotetext{
*Correspondence: Dr M Ozawa; E-mail: myukku12@hotmail.com or Professor H Taniguchi; E-mail: rtanigu@med.yokohama-cu.ac.jp ${ }^{7}$ These authors contributed equally to this work
} 
standard tumourigenicity assays. To address this deficiency, we used cancer cells derived directly from clinical samples of primary CRC lesions to evaluate the impact of several CSC markers, including CD133 and CD44 variants, on tumourigenesis and prognosis.

\section{MATERIALS AND METHODS}

Experiment 1. The tumourigenicity of enriched CD133- and CD44-positive cells from CRC patients was estimated using a xenograft model in NOD/SCID mice.

Samples. Suitable clinical samples (volume $>1 \mathrm{~cm}^{3}$ ), including CRC and adjacent normal mucosa, were obtained following surgical resection in 77 CRC patients at Yokohama City University Hospital, Yokohama City University Medical Center and Kanagawa Cancer Center from April 2007 to August 2011. We followed the approved guidelines set by the ethical committee at each institution (permitted no. 18-2B-14, no. 21142 and no. 9). The cancer specimens were immediately minced and filtered through $100-\mu \mathrm{m}$ nylon mesh and washed with calcium/magnesium-free PBS. To dissociate the cells, the specimens were incubated in Hank's balanced salt solution with 1\% EGTA and 1\% antibioticantimycotic (Life Techonologies, Inc., Rockville, MD, USA) at $37^{\circ} \mathrm{C}$ for $30 \mathrm{~min}$ and then placed in DMEM with $10 \%$ FBS supplemented with $2 \mathrm{mg} \mathrm{ml}^{-1}$ type IV collagenase (Sigma-Aldrich, St Louis, MO, USA) at $37^{\circ} \mathrm{C}$ for $1 \mathrm{~h}$. The cells were then filtered through a $40-\mu \mathrm{m}$ nylon mesh and washed twice.

Flow cytometric sorting. The dissociated cells of each sample were analysed and separated by a Moflo cell sorter (Beckman Coulter, Brea, CA, USA). Single-cell suspensions were incubated with allophycocyanin (APC)-conjugated anti-human CD133/1 (clone AC133; Miltenyi-Biotec, Bergisch Gladbach, Germany), phycoerythrin (PE)-conjugated anti-human CD44 (clone G44-26; BD Pharmingen, BD Biosciences, San Jose, CA, USA), biotinylated antihuman CD45 (clone HI30; eBioscience, San Diego, CA, USA) and anti-human CD235a (clone HIR2; eBioscience) for $30 \mathrm{~min}$ on ice. Streptavidin-APC-Cy7 (BD Pharmingen) was used as the secondary antibody. Doublet cells were excluded based on pulse width and forward scatter. Dead cells were excluded based on propidium iodide uptake. After removal of $\mathrm{CD} 45^{+} \mathrm{CD} 235 \mathrm{a}^{+}$haematopoietic cells, the fractionated cells were separated into the following sub-populations: $\mathrm{CD}_{133^{+}}, \mathrm{CD}_{133^{-}}, \mathrm{CD} 44^{+}, \mathrm{CD} 44^{-}, \mathrm{CD} 133^{+} \mathrm{CD} 44^{+}, \mathrm{CD} 133^{+}$ $\mathrm{CD}_{4}{ }^{-}, \mathrm{CD}_{133}{ }^{-} \mathrm{CD} 44^{+}$and $\mathrm{CD} 133^{-} \mathrm{CD} 44^{-}$.

Xenografts formed by total cell injection were analysed by cell sorting. Murine haematopoietic cells were excluded by using antimouse antibodies: CD45 (clone 20-F11; BD Pharmingen), Ter119 (clone TER-119; BD Pharmingen) and $\mathrm{H}_{2} \mathrm{~K}^{\mathrm{d}}$ (clone SF1-1.1; BD Pharmingen).

In vivo tumourigenesis assay. We were able to perform the tumourigenesis assay in 63 of 77 cases. Unsorted total cells or marker-enriched sub-populations from cancer specimens were suspended in $100 \mu \mathrm{l}$ of media and mixed with $100 \mu \mathrm{l}$ of Matrigel (BD Bioscience). Increasing numbers of cells were injected subcutaneously into 6-week-old female NOD/SCID mice (Sankyo Lab, Tokyo, Japan) under anaesthesia. Tumourigenesis was defined by detection of neoplasms with an external calliper every week up to 20 weeks after injection. When the tumours reached a diameter of $>2 \mathrm{~cm}$, the mice were killed and the tumours were excised and designated as the first xenograft.

NOD/SCID mice were maintained and operated upon in accordance with protocols approved by the Laboratory Animal Resource Center of Yokohama City University (no. 7). Surgery was performed under anaesthesia induced with isoflurane (Mylan, Osaka, Japan). The results of the tumourigenesis assays were used to calculate the regenerative cell frequency in each sorted fraction by limiting dilution analysis (Hu and Smyth, 2009).

Immunofluorescence. The 77 clinical samples of cancers and adjacent normal mucosa and the resected xenografts were immediately embedded in OCT compound (Sakura Finetek Japan, Tokyo, Japan) for immunohistochemistry. Frozen sections were fixed with $4 \%$ paraformaldehyde at room temperature (RT) for $10 \mathrm{~min}$. The sections were washed with PBS, treated with Block Ace (Dainippon Sumitomo Pharm Co. Ltd, Osaka, Japan) at RT for $1 \mathrm{~h}$ and incubated with primary antibodies overnight at $4{ }^{\circ} \mathrm{C}$. The slides were washed with PBS and then incubated with secondary antibodies at RT for $1 \mathrm{~h}$. Finally, slides were washed and the nuclei were counterstained with $4^{\prime}$, 6-diamidino-2-phenylindole. The antibodies used in this study were anti-human CD133 mAb (clone AC133; Miltenyi-Biotec), PE-conjugated anti-human CD44 MAb (clone G44-26; BD Pharmingen) and anti-human Ki67 MAb (clone MIB-1; Dako, Glostrup, Denmark).

Gene expression assay. The expression of stem cell markerrelated mRNAs was examined using five sets of normal mucosa, primary tumour tissues and xenografts derived from the same patients. Total RNA was isolated from each sample using an RNeasy Mini kit (Qiagen, Hilden, Germany). Complementary DNA (cDNA) was synthesised from $1 \mu \mathrm{g}$ of total RNA using a High-Capacity cDNA Reverse transcription Kit (Applied Biosystems, Foster City, CA, USA). Quantitative real-time PCR was performed with a LightCycler 480 Instrument (Roche Diagnostics, Basel, Switzerland). The PCR primer sequences are shown in Supplementary Table 1.

RT-PCR and exon-specific PCR. qRT-PCR was performed for standard and variant isoforms of CD44 (CD44s and CD44v). Variant isoform 1 (exon 6) contains a stop codon in humans; thus, CD44v1 is not expressed (Solis et al, 2012). Therefore, the remaining variant exons 2-10 (v2-10) were examined.

Primer design (Supplementary Table 2) and nested PCR were performed as described previously (Konig et al, 1996 and Rajarajan et al, 2012).

First-strand cDNA was synthesised from $0.5 \mu \mathrm{g}$ of total RNA using $10 \mathrm{ng} \mathrm{l}^{-1}$ oligo (dT) 12-18 primers (Life Technologies, Inc., Paisley, UK) with an initial denaturation step at $65^{\circ} \mathrm{C}$ for $5 \mathrm{~min}$. The samples were then placed on ice at for least $1 \mathrm{~min}$, and $5 \times$ first-strand buffer, $5 \mathrm{~mm}$ dithiothreitol (Life Technologies, Inc., Rockville, MD, USA), and each dNTP at $0.5 \mathrm{~mm}$ were added to each sample. SuperScript III reverse transcriptase (Invitrogen, Carlsbad, CA, USA) was added at a final concentration of $10 \mathrm{U}^{-1}$ and the sample was incubated for $60 \mathrm{~min}$ at $50^{\circ} \mathrm{C}$. A 15 -min incubation at $70{ }^{\circ} \mathrm{C}$ was performed to terminate the reaction.

Hot-start PCR was performed using cDNA primers for total CD44, individual variant exons (CD44v R and CD44v F, exonspecific forward primers for v2 to v10) (Konig et al, 1996; Rajarajan et al, 2012) and GAPDH (see Supplementary Table 2 for primer sequences).

A sample containing $1 \mu \mathrm{l}$ of cDNA, $5 \mathrm{~mm}$ Tris- $\mathrm{HCl}$ ( $\mathrm{pH} 7.5$ ), $3.2 \mathrm{mM} \mathrm{MgCl}_{2}$, each dNTP at $40 \mathrm{~mm}$, and each forward and reverse primer at $5 \mathrm{mM}$ was denatured for $2 \mathrm{~min}$ at $94{ }^{\circ} \mathrm{C}$, and $1.0 \mathrm{U} \mu \mathrm{l}^{-1}$ KOD FX (Toyobo, Osaka, Japan) was added. Amplification of cDNA was performed in a GeneAMP PCR System 9700 using 30 cycles for total $\mathrm{CD} 44$ and 25 cycles for GAPDH, respectively. Each cycle included denaturation for $10 \mathrm{~s}$ at $98^{\circ} \mathrm{C}$, annealing for $30 \mathrm{~s}$ at $57^{\circ} \mathrm{C}$ and elongation for $2 \mathrm{~min}$ at $68^{\circ} \mathrm{C}$. A second PCR reaction was performed for individual exon-specific PCRs from v2 to v10 and total variants using 20 cycles of denaturation for $10 \mathrm{~s}$ at $98^{\circ} \mathrm{C}$, annealing for $30 \mathrm{~s}$ at $58^{\circ} \mathrm{C}$ and elongation for $1.5 \mathrm{~min}$ at $68^{\circ} \mathrm{C}$. The reaction products were resolved by electrophoresis on a $1.5 \%$ agarose gel.

Experiment 2. A previously developed cDNA library (Oshima et $a l, 2008)$ that included 167 pairs of CRCs and their adjacent 
normal mucosa was utilised. Quantitative PCR was performed as described above (see 'Gene expression assay' section). The PCR primer sequences were as follows: CD133 (Prominin1) (forward: 5'-ACAACACTACCAAGGACAAGG-3', reverse: 5'-GGACTTAA TCTCATCAAGAACAGG-3'); CD44 (forward: 5'-CAGGAAGAA GGATGGATATGG-3' ${ }^{\prime}$, reverse: $5^{\prime}$-ATTACTCTGCTGCGTTGTC-3'); and LGR5 (forward: $5^{\prime}$-CCCGACGGCAGGATGTTG-3', reverse: 5'-GGAGGTGAAGACGCTGAGG-3' ${ }^{\prime}$ ).

A CD44 primer was designed to determine whether variant isoform 2 (exon 7) was associated with the patients' prognosis. The data associated with this primer are referred to as 'CD44v2'.

The clinicopathological characteristics of patients were classified according to the TNM classification for malignant tumours (Sobin et al, 2009).

Statistical analysis. Categorical variables are presented as the mean \pm s.d. A univariate analysis was performed using the MannWhitney nonparametric test, where appropriate, for continuous variables, and the $\chi^{2}$ test was used for categorical variables. A multivariate analysis was performed using the Cox proportional hazard regression model. Overall survival (OS) rates were calculated using the Kaplan-Meier method, and differences were evaluated using the log-rank test. Significance tests were two-tailed, and the level for significance was $P<0.05$. The SPSS 18 statistical package was used for all calculations (SPSS Inc., Chicago, IL, USA).

A multivariate analysis should ideally include a maximum of 3 variables and analyse 10 events per variable. Therefore, the TNM factor was defined as the TNM stage and analysed in association with adjuvant chemotherapy and CD44 expression.

\section{RESULTS}

$\mathrm{CD}_{133}{ }^{+}, \mathrm{CD}_{4}{ }^{+}$and $\mathrm{CD} 133^{+} \mathrm{CD}^{+} 4^{+}$cells isolated from CRC samples are tumourigenic. We first compared the frequency of cells with different immunophenotypes in cancerous $(n=77)$ vs normal mucosa $(n=20)$. The following frequencies were observed: $\mathrm{CD}_{133}{ }^{-} \mathrm{CD}_{4} 4^{-}, \quad 57.4 \pm 22.3 \%$ vs $70.9 \pm 3.0 \% \quad(P=0.001)$; $\mathrm{CD}_{133}{ }^{+} \mathrm{CD}_{4}{ }^{-}, 3.2 \pm 5.0 \%$ vs $1.2 \pm 0.8 \%(P=0.001)$; $\mathrm{CD} 133^{-}$ $\mathrm{CD} 44^{+}, \quad 21.1 \pm 14.9 \%$ vs $25.2 \pm 10.8 \% \quad(P=0.249) ; \mathrm{CD}^{+} 33^{+}$ $\mathrm{CD}_{4}{ }^{+}$was a very minor sub-population in both the cancerous and normal mucosa $(1.7 \pm 1.6 \%$ vs $1.4 \pm 1.2 \% ; \quad P=0.468$; Figure 1A). We used flow cytometry to enrich populations of cells expressing the various CSC markers in 77 CRC samples and obtained an adequate cell number in 63 out of 77 samples for use
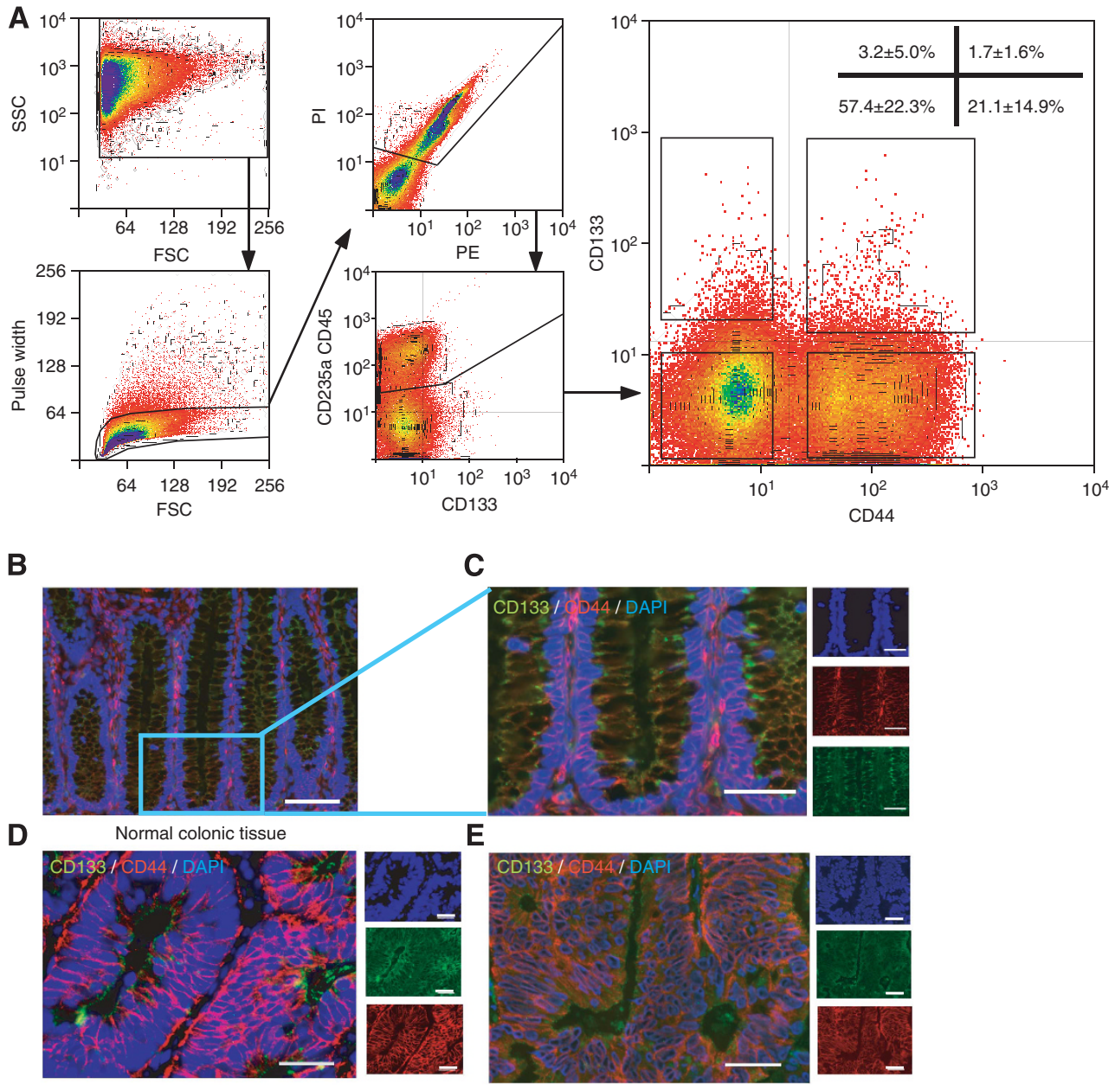

C
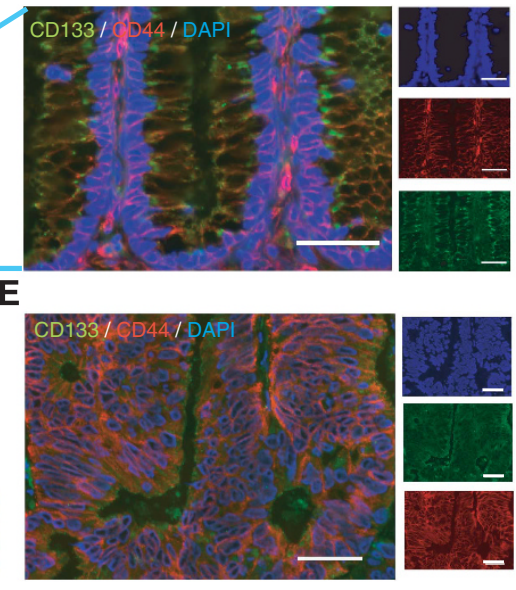

Primary tumour

Xenograft

Figure 1. Flow cytometric analysis of CRC cells and immunofluorescent staining of normal mucosa, primary tumour and xenograft tissue. Total CRC cells were stained with monoclonal antibodies and analysed by FACS (A). Haematopoietic cells were excluded with a leukocyte marker (CD45) and the erythroid cell marker CD235a. Non-haematopoietic (CD45- CD235a ${ }^{-}$) cells were fractionated with antibodies directed against CD133 and CD44. The ratios of the gated cells are included in the panel (mean \pm s.d., $n=77$ ). Staining patterns of CD133 and CD44 in normal human colonic mucosa (B). CD44 immunostaining was restricted to cells at the base of the crypt. CD133 staining was present from the crypt base to the transmembrane lesion (C). CD133 and CD44 were broadly observed in human colonic cancer and xenografts (D and E). Scale bar, $300 \mu \mathrm{m}$ in (B) and $50 \mu \mathrm{m}$ in (C-E). 
in tumourigenicity assays. The profiles of the 63 patients whose cells were used in the tumourigenesis assay are shown in Table 1. We found that 21 samples were tumourigenic, whereas the

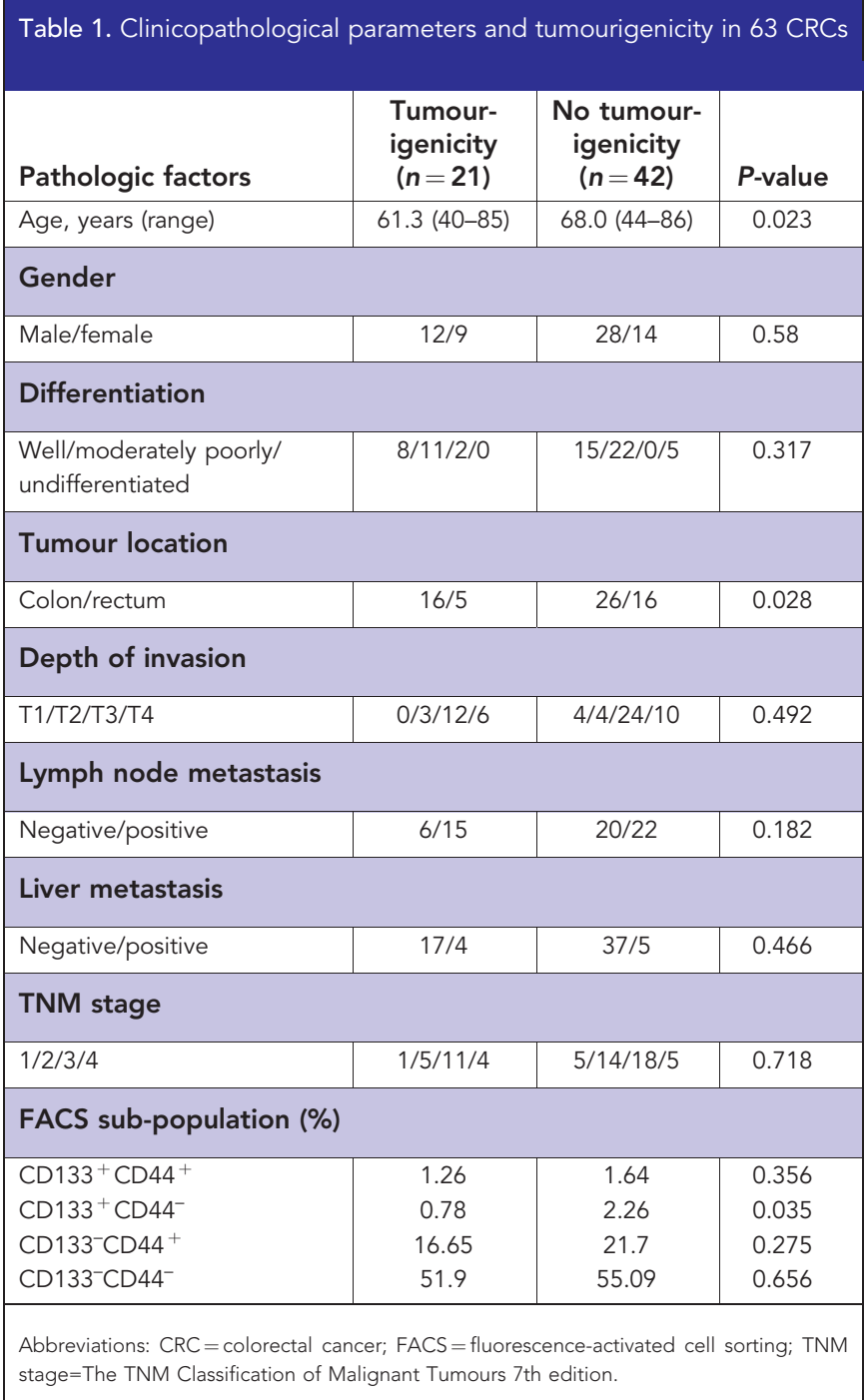

remaining 42 samples failed to produce palpable tumours during the 20-week experiment.

The results of the tumourigenesis assay are shown in Table 2. Calculation of the CSC frequency revealed that the $\mathrm{CD} 44^{+}$and $\mathrm{CD}_{133^{+}}$fractions were significantly more tumourigenic than the non-enriched population. In contrast, $\mathrm{CD} 133^{-}$and $\mathrm{CD} 44^{-}$cells were less tumourigenic in this context. The $\mathrm{CD} 133^{+} \mathrm{CD} 44^{+}$ fraction displayed the highest CSC frequency (1 out of 3160), and only the $\mathrm{CD} 44^{+}$and $\mathrm{CD} 133^{+} \mathrm{CD} 44^{+}$fractions were able to initiate tumours upon injection of the lowest number $\left(10^{2}\right)$ of cells. There was no statistical difference between the $\mathrm{CD}_{4}{ }^{+}$and $\mathrm{CD} 44^{+} \mathrm{CD} 133^{+}$fractions with regard to tumourigenicity.

Distribution of $\mathrm{CD} 33^{+}$and $\mathrm{CD}^{+}{ }^{+}$cells in clinical CRC samples. Immunofluorescence revealed broad CD133 expression from the crypt base to the epithelial cells in normal colonic mucosa. In contrast, CD44 expression was limited to cells between the crypt base and the transiently amplifying cell compartment (Figure $1 \mathrm{~B}$ and $\mathrm{C}$ ). Colorectal cancer samples presented high expression of CD44 throughout the mucosa. Some cells were also positive for CD133 (Figure 1D). This immunophenotype was also recapitulated in the xenografts (Figure 1E).

$\mathrm{CD}^{+}{ }^{+}$and $\mathrm{CD} 33^{+} \mathrm{CD}^{+}{ }^{+}$fractions are highly enriched in CSC xenografts. Flow cytometric analysis of the xenografts revealed that the proportion of $\mathrm{CD} 44^{+}$and $\mathrm{CD} 133^{+} \mathrm{CD} 44^{+}$cells was significantly higher in xenografts than in primary lesion ( $P=0.014, P=0.020$; Figure $2 \mathrm{~A})$. No significant differences in the frequencies of other markers were found in comparisons between primary lesions and xenografts.

Expression of other stem cell-related markers, including LGR5, Musashi-1, CD166, ALDH1, EphrinB2 and EphrinB3, tended to be higher in xenografts than in the primary lesion; however, this difference was not statistically significant (Figure 2B).

Proliferation of the $\mathrm{CD} 44^{+}$fraction was significantly higher in xenografts than in primary lesions. The frequency of Ki67 positivity was significantly higher in the $\mathrm{CD} 133^{+} \mathrm{CD} 44^{+}$and $\mathrm{CD} 133^{-} \mathrm{CD} 44^{+}$cells of xenografts than in cells from the primary lesions (Figure 2C). In contrast, the lack of Ki67 immunoreactivity in subsets of $\mathrm{CD} 133^{+} \mathrm{CD} 44^{-}$cells from both primary lesions and xenografts suggests that this population is non-cycling.

CD44 variant 2 is overexpressed in primary cancer and xenograft samples. The expression of $\mathrm{CD} 44 \mathrm{~s}$ and $\mathrm{CD} 44 \mathrm{v}$

Table 2. Tumourigenicity of CD133, CD44 and each of the combined sub-populations in NOD/SCID mouse xenografts

The ratio of tumour formation with the indicated cell number injected

\begin{tabular}{|c|c|c|c|c|c|c|c|}
\hline Cell populations & $10^{2}$ & $10^{3}$ & $10^{4}$ & $10^{5}$ & $10^{6}$ & $\begin{array}{l}\text { Cancer stem cell } \\
\text { frequency } \\
(95 \% \mathrm{Cl})\end{array}$ & $\begin{array}{c}P \text {-value } \\
\text { (vs total cells) }\end{array}$ \\
\hline Total cells & & $2 / 5(40 \%)$ & $13 / 19(68 \%)$ & 16/21 (76\%) & $6 / 8(75 \%)$ & 1/39 318 (1/63 691-1/24 272) & - \\
\hline $\mathrm{CD} 133^{+}$ & $0 / 2(0 \%)$ & $3 / 13(23 \%)$ & $1 / 3(33 \%)$ & & & $1 / 8940(1 / 26657-1 / 2999)$ & 0.022 \\
\hline $\mathrm{CD}^{\prime 33^{-}}$ & 0/1 (0\%) & 0/1 (0\%) & $3 / 16(19 \%)$ & $2 / 3(66 \%)$ & & $1 / 64145(1 / 165715-1 / 24829)$ & 0.311 \\
\hline $\mathrm{CD}_{4} 4^{+}$ & $1 / 3(33 \%)$ & $5 / 13(38 \%)$ & $0 / 2(0 \%)$ & & & $1 / 5111$ (1/14317-1/1825) & $<0.001$ \\
\hline $\mathrm{CD}_{4} 4^{-}$ & $0 / 4(0 \%)$ & $1 / 5(20 \%)$ & $2 / 13(15 \%)$ & $0 / 2(0 \%)$ & & 1/108 $249(1 / 392$ 006-1/29 892) & 0.059 \\
\hline $\mathrm{CD}_{133^{+}} \mathrm{CD}_{4} 4^{+}$ & $1 / 4(25 \%)$ & $4 / 8(50 \%)$ & $1 / 2(50 \%)$ & & & $1 / 3160(1 / 9518-1 / 1050)$ & $<0.001$ \\
\hline $\mathrm{CD}_{133^{+} \mathrm{CD}^{-} 4^{-}}$ & $0 / 6(0 \%)$ & $0 / 4(0 \%)$ & $0 / 2(0 \%)$ & & & - & - \\
\hline $\mathrm{CD}_{133^{-} \mathrm{CD} 44^{+}}$ & $0 / 2(0 \%)$ & $0 / 9(0 \%)$ & $2 / 6(33 \%)$ & & & 1/29317 (1/116 179-1/7398) & 0.703 \\
\hline $\mathrm{CD}_{133^{-} \mathrm{CD} 44^{-}}$ & $0 / 2(0 \%)$ & $1 / 5(20 \%)$ & $1 / 5(20 \%)$ & 0/1 (0\%) & & 1/74794 (1/409 064-1/13676) & 0.338 \\
\hline
\end{tabular}

Abbreviations: $\mathrm{Cl}=$ confidence interval; $\mathrm{CRC}=$ colorectal cancer; NOD-SCID = non-obese diabetic-severe combined immunodeficient. Limiting dilution analysis of the repopulating frequency of each fraction of sorted cells or unsorted total cells from CRC in clinical specimens. The cells were injected subcutaneously into NOD/SCID mice. Tumourigenesis was evaluated by measuring the size of the xenograft with an external calliper every week up to 20 weeks after injection. 
A

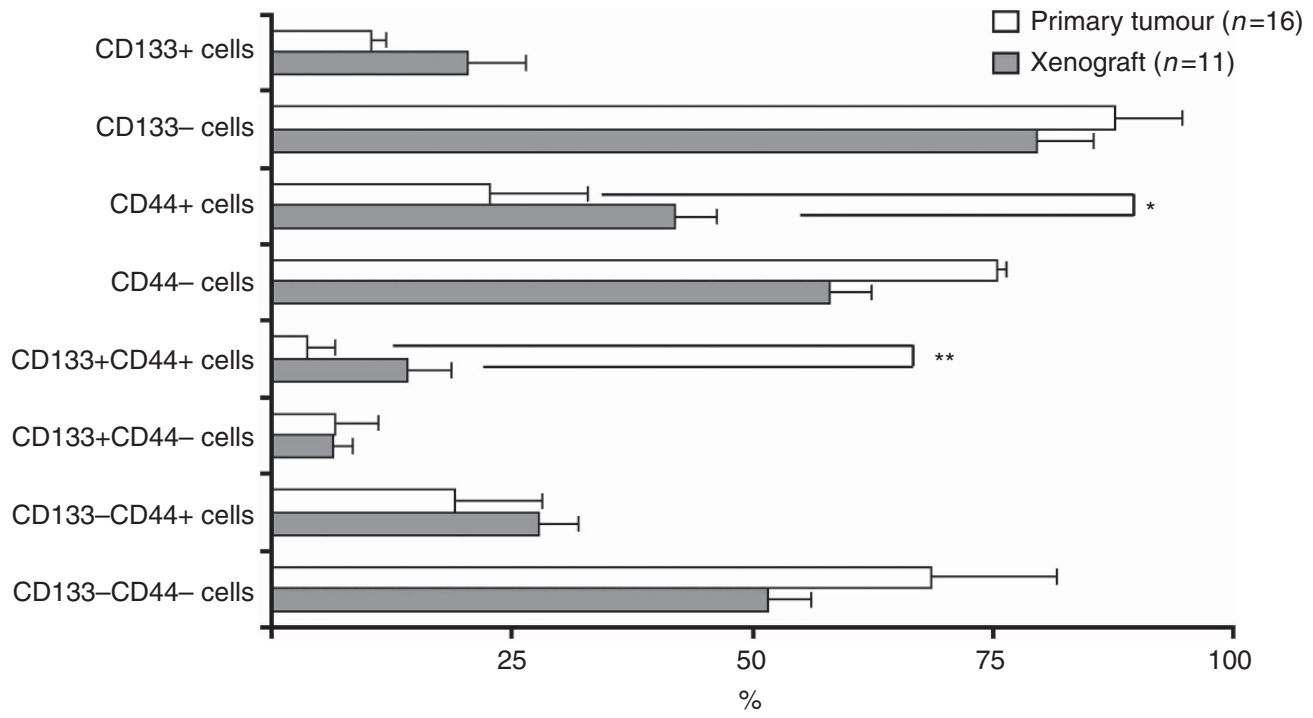

B

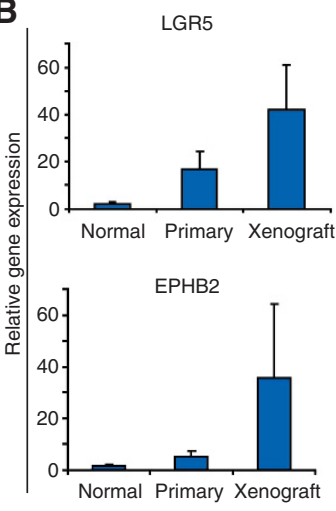

C

Primary tumour CD133/CD44/Ki67/DAPI

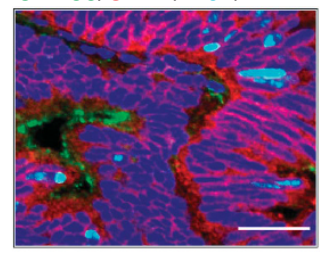

Xenograft CD133/CD44/Ki67/DAPI

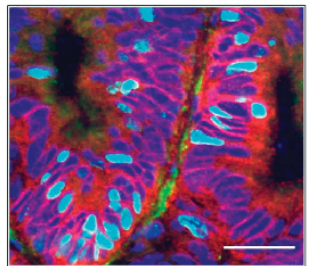

MSI-1
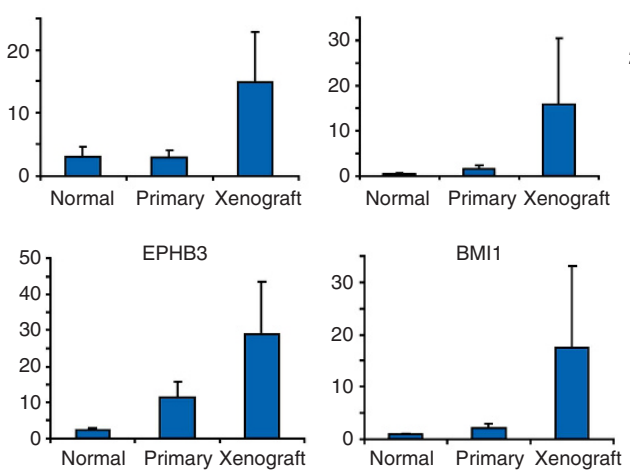

CD166

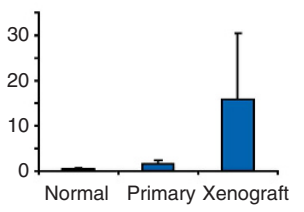

BMI1

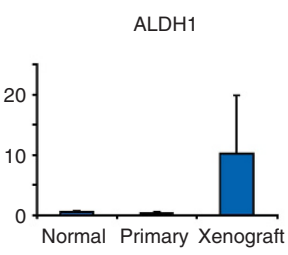

ABCB1

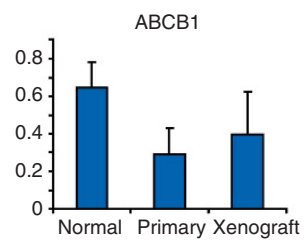

NANOG
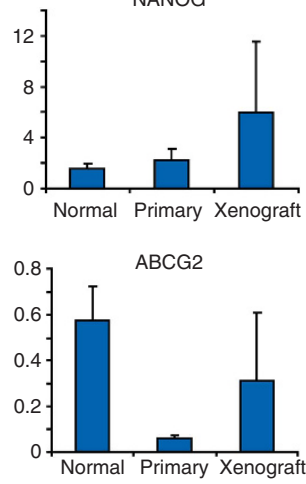

D

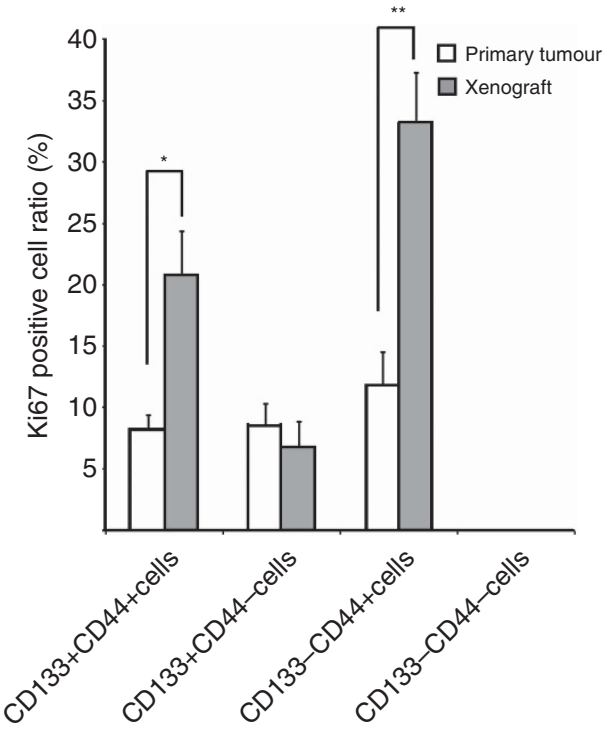

CD44v2

Set1 Set2 Set3 Set4 Set5 L N, P, X N,P, X N,P, X N,P, X N,P, X

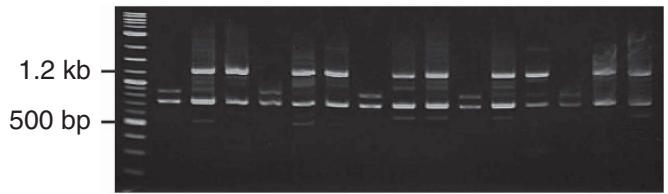

Figure 2. Comparison of cell sub-populations and gene expression in primary tumours and xenografts. The fraction of CD44 ${ }^{+}$and $\mathrm{CD} 133^{+} \mathrm{CD}_{4}{ }^{+}$cells is expanded in xenograft tumours $\left({ }^{\star} P=0.014,{ }^{\star \star} P=0.020\right)(\mathrm{A})$. qRT-PCR analysis of normal colon mucosa, primary tumours and xenografts $(n=5)$. The expression was normalised to that of B2M. Stemness genes were overexpressed in the xenografts (B). Cell proliferation indices were estimated in the primary tumours and xenografts by Ki67 immunohistochemistry. Subsets of CD133 ${ }^{+} \mathrm{CD} 44^{+}$and $\mathrm{CD} 133^{-} \mathrm{CD} 44^{+}$ cells in xenografts showed a significantly higher proliferative capacity than cells of primary tumours $\left(n=5,{ }^{\star} P=0.002\right.$, $\left.{ }^{\star *} P<0.001\right)$. Scale bar, $50 \mu$ m (C). RT-PCR analyses of CD44v2 expression. All five sets showed a similar increasing trend of CD44v2 overexpression in primary tumours and xenografts in comparison with the normal mucosa. Note the variant 2 -specific bands at $1.2 \mathrm{~kb}$. $\mathrm{L}=$ ladder; $\mathrm{N}=$ normal mucosa; $\mathrm{P}=$ primary tumour; $X=$ xenograft $(n=5)(D)$. The expression of standard total CD44, variant total CD44 and the individual exon-specific variants is shown in Supplementary Figure 1. 


\begin{tabular}{|c|c|}
\hline Pathologic factors & $n$ (frequency or range) \\
\hline Age, years & $65.4(40-90)$ \\
\hline \multicolumn{2}{|l|}{ Gender } \\
\hline Male & 92 (55\%) \\
\hline Female & 75 (45\%) \\
\hline Median follow-up period (months) & $38.8(0.8-70)$ \\
\hline \multicolumn{2}{|l|}{ Viability (5 years) } \\
\hline Died & $32(19 \%)$ \\
\hline Alive & 135 (81\%) \\
\hline Tumour diameter, mm & $46.1(13-130)$ \\
\hline \multicolumn{2}{|l|}{ Histological differentiation } \\
\hline Well & $51(31 \%)$ \\
\hline Moderately & 98 (59\%) \\
\hline Poorly & $8(5 \%)$ \\
\hline Undifferentiated & $10(6 \%)$ \\
\hline \multicolumn{2}{|l|}{ Tumour location } \\
\hline Colon & $93(56 \%)$ \\
\hline Rectum & $74(44 \%)$ \\
\hline \multicolumn{2}{|l|}{ Depth of invasion } \\
\hline T1 & $16(10 \%)$ \\
\hline T2 & $26(16 \%)$ \\
\hline T3 & $69(41 \%)$ \\
\hline T4 & 55 (33\%) \\
\hline \multicolumn{2}{|l|}{ Lymph node metastasis } \\
\hline Negative & 89 (53\%) \\
\hline Positive & $78(47 \%)$ \\
\hline \multicolumn{2}{|l|}{ Lymphatic invasion } \\
\hline Negative & 109 (65\%) \\
\hline Positive & $58(35 \%)$ \\
\hline \multicolumn{2}{|l|}{ Vascular invasion } \\
\hline Negative & $62(37 \%)$ \\
\hline Positive & 105 (63\%) \\
\hline \multicolumn{2}{|l|}{ Liver metastasis } \\
\hline Negative & 109 (65\%) \\
\hline Positive & $58(35 \%)$ \\
\hline \multicolumn{2}{|l|}{ TNM stage } \\
\hline 1 & $32(19 \%)$ \\
\hline 2 & $42(25 \%)$ \\
\hline 3 & $35(21 \%)$ \\
\hline 4 & $58(35 \%)$ \\
\hline \multicolumn{2}{|l|}{ Adjuvant chemotherapy } \\
\hline Negative & $123(74 \%)$ \\
\hline Positive & 44 (26\%) \\
\hline \multicolumn{2}{|l|}{5 -Year survival rate (\%) } \\
\hline Stage 1 & $100 \%$ \\
\hline Stage 2 & $95.20 \%$ \\
\hline Stage 3 & $88.60 \%$ \\
\hline Stage 4 & $55.20 \%$ \\
\hline
\end{tabular}

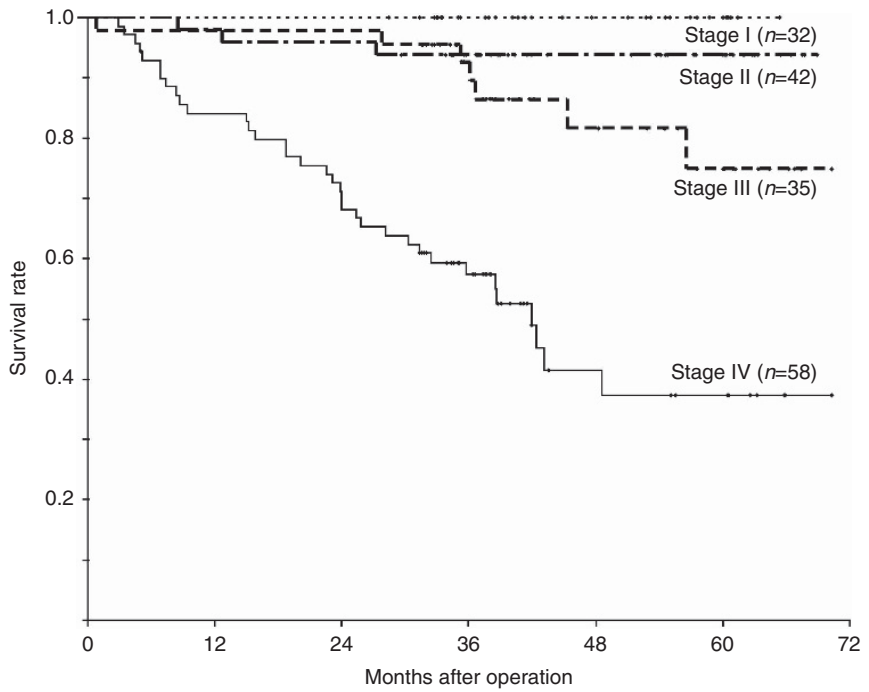

Figure 3. Kaplan-Meier curves by TMN stage.

(v2-10) was compared across five patient-derived sets of normal mucosa, primary cancer tissue and xenografts. As expected, the expression of CD44s was observed in all normal tissues and primary cancers; however, expression was difficult to detect in xenografts. CD44v3-10 was expressed in all samples, including xenografts (Supplementary Figure 1B). CD44v2 was specifically overexpressed in the cancerous tissue, particularly in the primary tumours and xenografts, when compared with the normal mucosa (Figure 2D).

CD44v2 is a clinical prognostic factor in CRC. The profiles of 167 patients are shown in Table 3, and the Kaplan-Meier curves in relation to the TNM stage are shown in Figure 3. These samples did have expression patterns similar to those shown in the set of 63 samples in Table 1. A comparison of stem cell-related markers revealed that the expression of CD133, CD44v2, LGR5 (Figure 4A), EphB2 and Musashi-1 (data not shown) was significantly higher in cancerous lesions than in normal mucosa, whereas there was no difference in the expression of Bmil and NANOG (data not shown). We did not find any significant correlations among the expression levels of CD133, CD44v2, LGR5, EphB2 and Musashi-1.

The median value for the expression of each marker was determined as a cut off value, and this threshold was used to divide the 167 patients into two groups of 'high' and 'low' expression. Overall survival was then compared between these two groups for each of the markers, and the results of the Kaplan-Meier analysis are shown in Figure 4B. The prognosis of the CD44v2 ${ }^{\text {high }}$ group $(n=84,5$-year survival rate (5-OS): 0.74$)$ was significantly worse $(P=0.041)$ than that of the CD $44 \mathrm{v} 2^{\text {low }}$ group $(n=83,5$-OS: 0.88$)$. There were 32 deaths among the 167 patients in the cohort. Multivariate analysis revealed that CD44v2 is an independent prognostic factor for survival (Table 4). Stratification based on expression of CD133, LGR5, EphB2 and Musashi-1 was not a successful prognostic indicator (data not shown). Each SC marker was combined with each of the different markers and the OS of each group was calculated. The OS of patients in the CD $133^{\text {high }}$ CD $44^{\text {high }}$ group $(n=56,5$-OS: 0.77$)$ was not significantly worse than that of patients in the other groups $(n=111$, 5-OS: 0.83; Figure 4B). However, the prognosis of the CD $44^{\text {high }}$ LGR $^{\text {high }}$ group ( $n=48,5$-OS: 0.68$)$ was significantly worse than that of the other groups $(n=132,5$-OS: 0.86$)$. The CD $133^{\text {high }} \mathrm{CD} 44^{\text {high }}$ LGR $5^{\text {high }}$ group ( $n=35$ 5-OS: 0.68$)$ also showed a worse prognosis than the other groups $(n=132,5$-OS: 0.84). No other combination of markers with either CD133 or CD44 was correlated with prognosis. 

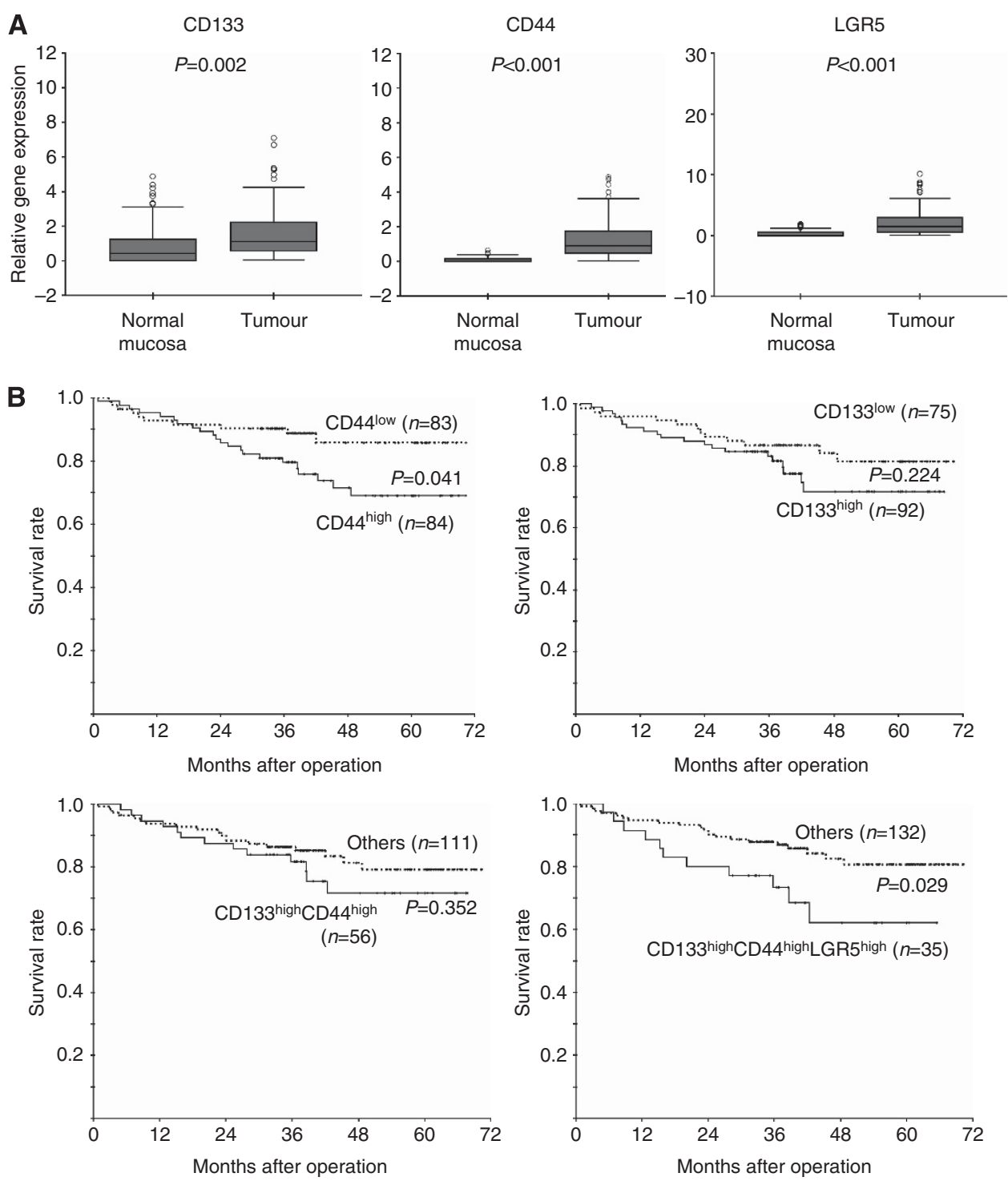

Figure 4. Correlation of CD133, CD44 and LGR5 expression in normal and cancerous mucosa, and OS ( $n=167)$. The markers were significantly overexpressed in the xenografts $(P=0.002, P<0.001$ and $P<0.001)(A)$. Kaplan-Meier analysis of OS in patients according to the level of CD133, CD44, CD133/CD44 and CD133/CD44/LGR5 expression as determined by qRT-PCR (B).

The influence of CD44v2 was analysed in relation to disease stage. In stage IV patients, the CD $44^{\text {high }}$ immunophenotype showed a significantly poorer prognosis than the CD44 low group ( $n=28$ 5-OS: 0.36 vs $n=30$ 5-OS: $0.73 ; P=0.03$, respectively). There was no clear distinction based on marker expression in patients with stages I-III disease.

\section{DISCUSSION}

Here, we confirm that CD44 and CD133 are important CSC markers, and that CD44 is a significant predictor of tumourigenic potential and prognosis in primary CRC lesions. $\mathrm{CD} 133^{+}$cells were previously identified as tumour-initiating cells (TICs) in CRCs using 17 clinical samples (O'Brien et al, 2007), which was supported by the finding that CD133 has a role in the tumourigenicity of CRC cell lines (Yang et al, 2011). However, whether CD133 is strictly required for tumour initiation is unclear, as a CRC-derived CD133- ${ }^{-}$cancer cell line was found to retain tumour-initiating potential (NavarroAlvarez et al, 2010). CD44 is also an important determinant of CRC malignant behaviour. Expression of CD44 splice variants in CRC was suggested to be a marker of cancer malignant potential (Jackson et al, 1992; Screaton et al, 1992; Wielenga et al, 1993). However, studies of CD44 are also contradictory, as firm conclusions are hampered by nonspecific CD44 variant isoforms found in different tissue sources and in different laboratories (Al-Maghrabi et al, 2012; Ohata et al, 2012; Saito et al, 2013). Until this study, the importance of CD44v2 in cancer initiation and tumour cell maintenance was unclear. Here, we found that CD44v2 expression increased in xenograft tumours derived from clinical CRC specimens. However, our data do not diminish the importance of CD44v3 or v6, which are well-established markers in CRC. Future studies may identify new factors to improve the prediction of poor outcome. In tumourigenicity assays, CD44 was previously identified as a marker of stem-like TIC in colon cancer using 15 clinical samples (Chu et al, 2009). The $\mathrm{CD}_{133}{ }^{+} \mathrm{CD} 44^{+}$phenotype has also been reported to be associated with a highly enriched population of cancer-initiating cells (Haraguchi et al, 2008) and may also represent a metastatic subset of CRCs (Chen et al, 2011). Here, we found that both $\mathrm{CD}_{133^{+}}$cells and $\mathrm{CD} 44^{+}$cells are significantly more tumourigenic than total (non-enriched) cells and $\mathrm{CD}_{4}{ }^{+}$cells. Indeed, 1 TIC was found for every 5111 cells (Table 2), a frequency higher than that observed for $\mathrm{CD} 33^{+}$cells (1 out of 8940); 
Table 4. Prognostic factors for overall survival of CRCs

\begin{tabular}{|c|c|c|c|c|c|c|}
\hline \multirow[b]{2}{*}{ Variables } & \multirow[b]{2}{*}{$n$} & \multicolumn{3}{|c|}{ Univariate analysis } & \multicolumn{2}{|c|}{ Multivariate analysis } \\
\hline & & Hazard ratio $(95 \% \mathrm{Cl})$ & 5 -year OS (\%) & $P$-value & Hazard ratio $(95 \% \mathrm{Cl})$ & $P$-value \\
\hline \multicolumn{7}{|l|}{ Age } \\
\hline $\begin{array}{l}<70 \\
\geqslant 70\end{array}$ & $\begin{array}{r}107 \\
60\end{array}$ & $\begin{array}{c}1 \\
1.390(0685-2.820)\end{array}$ & $\begin{array}{l}82.2 \\
78.3\end{array}$ & 0.362 & & \\
\hline \multicolumn{7}{|l|}{ Gender } \\
\hline $\begin{array}{l}\text { Female } \\
\text { Male }\end{array}$ & $\begin{array}{l}75 \\
92\end{array}$ & $\begin{array}{c}1 \\
1.092(0.542-2.198)\end{array}$ & $\begin{array}{l}81.3 \\
80.4\end{array}$ & 0.8058 & & \\
\hline \multicolumn{7}{|c|}{ Tumour diameter $(\mathrm{mm})$} \\
\hline $\begin{array}{l}<50 \\
\geqslant 50\end{array}$ & $\begin{array}{l}96 \\
71\end{array}$ & $\begin{array}{c}1 \\
3.887(1.798-8.403)\end{array}$ & $\begin{array}{l}90.6 \\
67.6\end{array}$ & $<0.001$ & & \\
\hline \multicolumn{7}{|l|}{ Differentiation } \\
\hline $\begin{array}{l}\text { Poorly/undifferentiated } \\
\text { Well/moderately }\end{array}$ & $\begin{array}{r}18 \\
149\end{array}$ & $\begin{array}{c}1 \\
0.538(0.207-1.400)\end{array}$ & $\begin{array}{l}72.2 \\
81.8\end{array}$ & 0.2043 & & \\
\hline \multicolumn{7}{|l|}{ Depth of invasion } \\
\hline $\begin{array}{l}\mathrm{T} 1, \mathrm{~T} 2 \\
\mathrm{~T} 3, \mathrm{~T} 4\end{array}$ & $\begin{array}{r}42 \\
124\end{array}$ & $\begin{array}{c}1 \\
11.90(1.624-87.155)\end{array}$ & $\begin{array}{l}92.6 \\
75\end{array}$ & 0.0148 & & \\
\hline \multicolumn{7}{|l|}{ Tumour location } \\
\hline $\begin{array}{l}\text { Colon } \\
\text { Rectum }\end{array}$ & $\begin{array}{r}41 \\
125\end{array}$ & $\begin{array}{c}1 \\
1.262(0.631-2.524)\end{array}$ & $\begin{array}{l}80.5 \\
81\end{array}$ & 0.8915 & & \\
\hline \multicolumn{7}{|c|}{ Lymph node metastasis } \\
\hline $\begin{array}{l}\text { Negative } \\
\text { Positive }\end{array}$ & $\begin{array}{l}89 \\
78\end{array}$ & $\begin{array}{c}1 \\
5.041(2.176-11.678)\end{array}$ & $\begin{array}{l}92.1 \\
68\end{array}$ & $<0.001$ & & \\
\hline \multicolumn{7}{|l|}{ Liver metastasis } \\
\hline $\begin{array}{l}\text { Negative } \\
\text { Positive }\end{array}$ & $\begin{array}{r}109 \\
58\end{array}$ & $\begin{array}{c}1 \\
11.400(4.660-27.886)\end{array}$ & $\begin{array}{l}94.5 \\
55.2\end{array}$ & $<0.001$ & & \\
\hline \multicolumn{7}{|l|}{ TNM stage } \\
\hline $\begin{array}{l}1 / 2 \\
3 / 4\end{array}$ & $\begin{array}{l}74 \\
93\end{array}$ & $\begin{array}{c}1 \\
15.423(3.675-64.721)\end{array}$ & $\begin{array}{l}97.3 \\
67.7\end{array}$ & $<0.001$ & $\begin{array}{c}1 \\
26.768(6.294-113.839)\end{array}$ & $<0.001$ \\
\hline \multicolumn{7}{|c|}{ Adjuvant chemotherapy } \\
\hline $\begin{array}{l}\text { Negative } \\
\text { Positive }\end{array}$ & $\begin{array}{r}123 \\
44\end{array}$ & $\begin{array}{c}1 \\
0.166(0.196-1.323)\end{array}$ & $\begin{array}{l}78.1 \\
88.6\end{array}$ & 0.1576 & $\begin{array}{c}1 \\
0.189(0.072-0.496)\end{array}$ & $<0.001$ \\
\hline \multicolumn{7}{|l|}{ CD133 expression } \\
\hline $\begin{array}{l}\text { Low } \\
\text { High }\end{array}$ & $\begin{array}{l}75 \\
92\end{array}$ & $\begin{array}{c}1 \\
1.556(0.759-3.193)\end{array}$ & $\begin{array}{l}84 \\
78.3\end{array}$ & 0.2238 & & \\
\hline \multicolumn{7}{|l|}{ CD44 expression } \\
\hline $\begin{array}{l}\text { Low } \\
\text { High }\end{array}$ & $\begin{array}{l}83 \\
84\end{array}$ & $\begin{array}{c}1 \\
2.140(1.013-4.522)\end{array}$ & $\begin{array}{l}88 \\
73.8\end{array}$ & 0.0462 & $\begin{array}{c}1 \\
2.530(1.193-5.364)\end{array}$ & 0.0155 \\
\hline \multicolumn{7}{|l|}{ LGR5 expression } \\
\hline $\begin{array}{l}\text { Low } \\
\text { High }\end{array}$ & $\begin{array}{l}82 \\
95\end{array}$ & $\begin{array}{c}1 \\
1.541(0.761-3.122)\end{array}$ & $\begin{array}{l}84.2 \\
77.6\end{array}$ & 0.2263 & & \\
\hline
\end{tabular}

however, the difference was not statistically significant. CD133 ${ }^{+}$ $\mathrm{CD}_{4}{ }^{+}$cells were also highly tumourigenic (1 out of 3160 ) in comparison with $\mathrm{CD} 133^{+} \mathrm{CD} 44^{-}$cells, whereas $\mathrm{CD} 133^{-} \mathrm{CD} 44^{+}$ cells were weakly tumourigenic (1 out of 29317). The significant increase in the fraction of $\mathrm{CD}_{4} 4^{+}$and $\mathrm{CD} 133^{+} \mathrm{CD} 44^{+}$cells in xenografts compared with primary tumours (Figure 2A) also underscores the important role of these sub-populations during tumourigenesis. Notably, the $\mathrm{CD} 133^{+}$fraction did not undergo any 
obvious expansion. Although the $\mathrm{CD} 133^{+} \mathrm{CD} 44^{+}$immunophenotype has previously been associated with the most potent TICs in CRC (Haraguchi et al, 2008), we did not find any difference in their tumour-initiating potential when compared with $\mathrm{CD}_{4} 4^{+}$cells. Haraguchi et al (2008) also reported that the $\mathrm{CD} 133^{+} \mathrm{CD} 44^{-}$ population was not tumourigenic. Du et al (2008) compared the tumourigenicity of cells in which either CD44 or CD133 was silenced by lentiviral delivery of shRNA. Specifically, knockdown of CD44, but not CD133, inhibited clonal outgrowth and blocked tumourigenicity. Together, these results indicate that $\mathrm{CD}_{4} 4^{+}$is a robust marker of CSCs.

Our current study provides a clinically relevant perspective, as the tumourigenesis assay was performed exclusively with CRC cells derived from primary tumours. It has been suggested that cell lines do not recapitulate all aspects of primary tumours (O'Brien et al, 2007). Furthermore, most xenogeneic colon cancer models utilise cell lines, which have been selected for growth in culture and may therefore be more 'homogenous' than cells that constitute the primary tumour. Indeed, there is likely to be considerable heterogeneity both within and between tumours from different patients with CRC. In an attempt to more faithfully reproduce the process of tumour initiation from cancer-initiating cells, tumourigenesis assays using clinical samples have been performed (Chu et al, 2009). However, this study had limitations, as the cells were first cultured as xenografts in mice. Therefore, CRCs in metastatic lesions or in xenografts that express the same marker show significantly different biological behaviour relative to the cells in the primary tumour. Thus, we suggest that modelling the disease using the strategy described in this report is a more effective experimental approach.

The fraction of CD133- or CD44-positive cells is higher in metastatic liver disease than in CRC (O'Brien et al, 2007; Bellizzi et al, 2012). Here, we found that the proportion of Ki67-positive cells in the $\mathrm{CD} 133^{+} \mathrm{CD} 44^{+}$and $\mathrm{CD} 133^{-} \mathrm{CD} 44^{+}$fractions was higher in xenografts than in primary lesions (Figure 2C). Thus, our study confirms that both $\mathrm{CD} 133$ and $\mathrm{CD} 44$ are robust CSC markers in primary CRC lesions.

In addition to CD44 and CD133, many other molecules have been proposed to be CSC markers, including LGR5, MSI-1, CD166, ALDH-1, NANOG, BMI1, ABCB1 and ABCG2 (Sanders and Majumdar, 2011). In the this study, the expression of LGR5, MSI1, CD166, ALDH1, NANOG and Ephrin receptors tended to be higher in xenografts than in primary tumours and normal mucosa; however, this trend was not statistically significant (Figure 2B). We were thus unable to confirm the relevance of TIC markers other than CD133 and CD44.

There are contradictory reports regarding the prognostic significance of several CSC markers. For example, a high proportion of $\mathrm{CD}_{133^{+}}$cells is significantly associated with poor prognosis in some cases (Wang et al, 2009; Takahashi et al, 2011). However, one report suggested that CD133 overexpression is not associated with poor prognosis (Choi et al, 2009). Similarly, controversy exists regarding the utility of LGR5 and CD44 as prognostic markers (Horst et al, 2009; Saigusa et al, 2012). Combined expression of CD133 and CD44 is reportedly a prognostic indicator for diseasefree survival in patients with CRC (Galizia et al, 2012). We found that expression of CD133, CD44 and LGR5 was significantly higher in tumours than in normal tissue (Figure 4A), whereas expression of NANOG and BMI1 was equivocal. CD44 expression was an independent prognostic marker of poor OS, whereas expression of CD133, LGR5, EPHB2 and MSI-1 did not correlate with survival. Although the combination of CD133/CD44 was not a prognostic factor, the co-expression of CD133, CD44 and LGR5 was an independent prognostic factor. Despite the correlation in the latter case, the OS of the 'poor prognosis' group based on a $\mathrm{CD} 133^{\text {high }} \mathrm{CD} 44^{\text {high }} \mathrm{LGR} 5^{\text {high }}$ phenotype was almost the same as that in patients expressing CD $44^{\text {high }}$ alone.
In conclusion, the expression of CD44, particularly CD44 variant 2, is a well-established CSC and prognostic marker. Further research into the signalling pathways associated with CD44 upregulation will therefore provide a potential avenue for treatment and prognosis in patients with CRC.

\section{ACKNOWLEDGEMENTS}

This work was supported in part by Grants-in-Aid to Y-WZ (18591421, 20591531 and 23591872) for Scientific Research and by fund (11800122) for Creation of Innovation Centers for Advanced Interdisciplinary Research Areas Program in the Project for Developing Innovation Systems from the Ministry of Education, Culture, Sports, Science and Technology (MEXT) of Japan.

\section{CONFLICT OF INTEREST}

The authors declare no conflict of interest.

\section{REFERENCES}

Al-Maghrabi J, Gomaa W, Buhmeida A, Al-Qahtani M, Al-Ahwal M (2012) Decreased immunoexpression of standard form of CD44 is an independent favourable predictor of nodal metastasis in colorectal carcinoma. Anticancer Res 32: 3455-3461.

Bellizzi A, Sebastian S, Ceglia P, Centonze M, Divella R, Manzillo EF, Azzariti A, Silvestris N, Montemurro S, Caliandro C, De Luca R, Cicero G, Rizzo S, Russo A, Quaranta M, Simone G, Paradiso A (2012) Co-expression of CD133(+)/CD44(+) in human colon cancer and liver metastasis. J Cell Physiol 228: 408-415.

Chen KL, Pan F, Jiang H, Chen JF, Pei L, Xie FW, Liang HJ (2011) Highly enriched CD133 $(+) \mathrm{CD} 44(+)$ stem-like cells with CD133(+)CD44(high) metastatic subset in HCT116 colon cancer cells. Clin Exp Metastasis 28: 751-763.

Choi D, Lee HW, Hur KY, Kim JJ, Park GS, Jang SH, Song YS, Jang KS, Paik SS (2009) Cancer stem cell markers CD133 and CD24 correlate with invasiveness and differentiation in colorectal adenocarcinoma. World $J$ Gastroenterol 15: 2258-2264.

Chu P, Clanton DJ, Snipas TS, Lee J, Mitchell E, Nguyen ML, Hare E, Peach RJ (2009) Characterization of a subpopulation of colon cancer cells with stem cell-like properties. Int J Cancer 124: 1312-1321.

Dalerba P, Dylla SJ, Park IK, Liu R, Wang X, Cho RW, Hoey T, Gurney A, Huang EH, Simeone DM, Shelton AA, Parmiani G, Castelli C, Clarke MF (2007) Phenotypic characterization of human colorectal cancer stem cells. Proc Natl Acad Sci USA 104: 10158-10163.

Du L, Wang H, He L, Zhang J, Ni B, Wang X, Jin H, Cahuzac N, Mehrpour M, $\mathrm{Lu} \mathrm{Y}$, Chen Q (2008) CD44 is of functional importance for colorectal cancer stem cells. Clin Cancer Res 14: 6751-6760.

Galizia G, Gemei M, Del Vecchio L, Zamboli A, Di Noto R, Mirabelli P, Salvatore F, Castellano P, Orditura M, De Vita F, Pinto M, Pignatelli C, Lieto E (2012) Combined CD133/CD44 expression as a prognostic indicator of disease-free survival in patients with colorectal cancer. Arch Surg 147: 18-24.

Haraguchi N, Ohkuma M, Sakashita H, Matsuzaki S, Tanaka F, Mimori K, Kamohara Y, Inoue H, Mori M (2008) CD133 + CD44 + population efficiently enriches colon cancer initiating cells. Ann Surg Oncol 15: 2927-2933.

Horst D, Kriegl L, Engel J, Kirchner T, Jung A (2009) Prognostic significance of the cancer stem cell markers CD133, CD44, and CD166 in colorectal cancer. Cancer Invest 27(8): 844-850.

Hu Y, Smyth GK (2009) ELDA: extreme limiting dilution analysis for comparing depleted and enriched populations in stem cell and other assays. J Immunol Methods 347: 70-78.

Jackson DG, Buckley J, Bell JI (1992) Multiple variants of the human lymphocyte homing receptor CD44 generated by insertions at a single site in the extracellular domain. J Biol Chem 267: 4732-4739.

Jessup JM, Giavazzi R, Cambell D, Cleary KR, Morikawa K, Hostetter R, Atkinson EN, Fidler IJ (1989) Metastatic potential of human coloectal 
carcinoma implanted into nude mice: prediction of clinical outcome in patients operated upon for cure. Cancer Res 49(24 Pt 1): 6906-6910.

Konig H, Moll J, Ponta H, Herrlich P (1996) Trans-acting factors regulate the expression of CD44 splice variants. EMBO J 15: 4030-4039.

Navarro-Alvarez N, Kondo E, Kawamoto H, Hassan W, Yuasa T, Kubota Y, Seita M, Nakahara H, Hayashi T, Nishikawa Y, Hassan RA, Javed SM, Noguchi H, Matsumoto S, Nakaji S, Tanaka N, Kobayashi N, Soto-Gutierrez A (2010) Isolation and propagation of a human CD133(-) colon tumor-derived cell line with tumorigenic and angiogenic properties. Cell Transplant 19: 865-877.

O'Brien CA, Pollett A, Gallinger S, Dick JE (2007) A human colon cancer cell capable of initiating tumour growth in immunodeficient mice. Nature 445: 106-110.

Ohata H, Ishiguro T, Aihara Y, Sato A, Sakai H, Sekine S, Taniguchi H, Akasu T, Fujita S, Nakagama H, Okamoto K (2012) Induction of the stem-like cell regulator CD44 by Rho kinase inhibition contributes to the maintenance of colon cancer-initiating cells. Cancer Res 72: 5101-5110.

Oshima T, Akaike M, Yoshihara K, Shiozawa M, Yamamoto N, Sato T, Akihito N, Nagano Y, Fujii S, Kunisaki C, Wada N, Rino Y, Tanaka K, Masuda M, Imada T (2008) Overexpression of EphA4 gene and reduced expression of EphB2 gene correlates with liver metastasis in colorectal cancer. Int J Oncol 33: 573-577.

Rajarajan A, Stokes A, Bloor BK, Ceder R, Desai H, Grafstom CR, Odell EW (2012) CD44 expression in oro-pharyngeal carcinoma tissues and cell lines. PLoS One 7(1): e28776.

Reya T, Morrison SJ, Clarke MF, Weissman IL (2001) Stem cells, cancer, and cancer stem cells. Nature 414: 105-111.

Ricci-Vitiani L, Lombardi DG, Pilozzi E, Biffoni M, Todaro M, Peschle C, De Maria R (2007) Identification and expansion of human colon-cancerinitiating cells. Nature 445: 111-115.

Saigusa S, Inoue Y, Tanaka K, Toiyama Y, Matsushita K, Kawamura M, Okugawa Y, Hiro J, Uchida K, Mohri Y, Kusunoki M (2012) Clinical significance of LGR5 and CD44 expression in locally advanced rectal cancer after preoperative chemoradiotherapy. Int J Oncol 41: 1643-1652.

Saito S, Okabe H, Watanabe M, Ishimoto T, Iwatsuki M, Baba Y, Tanaka Y, Kurashige J, Miyamoto Y (2013) CD44v6 expression is related to mesenchymal phenotype and poor prognosis in patients with colorectal cancer. Oncol Rep 29: 1570-1578.

Sanders MA, Majumdar AP (2011) Colon cancer stem cells: implications in carcinogenesis. Front Biosci 16: 1651-1662.

Screaton GR, Bell MV, Jackson DG, Cornelis FB, Gerth U, Bell JI (1992) Genomic structure of DNA encoding the lymphocyte homing receptor CD44 reveals at least 12 alternatively spliced exons. Proc Natl Acad Sci USA 89: $12160-12164$.

Sobin LH, Gospodarowicz MK, Wittekind C (2009) TNM Classification of Malignant Tumours. 7th edn. Wiley-Blackwell: Hoboken, NJ.

Solis MA, Chen YH, Wong TY, Bittencourt VZ, Lin YC, Huang LH (2012) Hyaluronan regulates cell behavior: a potential niche matrix for stem cells. Biochem Res Int 2012: 346972.

Takahashi H, Ishii H, Nishida N, Takemasa I, Mizushima T, Ikeda M, Yokobori T, Mimori K, Yamamoto H, Sekimoto M, Doki Y, Mori M (2011) Significance of Lgr5( + ve) cancer stem cells in the colon and rectum. Ann Surg Oncol 18: 1166-1174.

Todaro M, Francipane MG, Medema JP, Stassi G (2010) Colon cancer stem cells: promise of targeted therapy. Gastroenterology 138: 2151-2162.

Wang Q, Chen ZG, Du CZ, Wang HW, Yan L, Gu J (2009) Cancer stem cell marker CD133 + tumour cells and clinical outcome in rectal cancer. Histopathology 55: 284-293.

Wielenga VJ, Heider KH, Offerhaus GJ, Adolf GR, van den Berg FM, Ponta H, Herrlich P, Pals ST (1993) Expression of CD44 variant proteins in human colorectal cancer is related to tumor progression. Cancer Res 53: 4754-4756.

Yang ZL, Zheng Q, Yan J, Pan Y, Wang ZG (2011) Upregulated CD133 expression in tumorigenesis of colon cancer cells. World J Gastroenterol 17: 932-937.

This work is published under the standard license to publish agreement. After 12 months the work will become freely available and the license terms will switch to a Creative Commons AttributionNonCommercial-Share Alike 3.0 Unported License.

Supplementary Information accompanies this paper on British Journal of Cancer website (http://www.nature.com/bjc) 